\title{
Applying OK4R to Embellish Reading Comprehension
}

\author{
Syaiful Islam ${ }^{1}$, Chusnul Muali ${ }^{2}$, Zaenol Fajri ${ }^{3}$, Niken Septantiningtyas ${ }^{4}$, Handono Fatkhur \\ Rahman $^{5}$ and Ahmad Fauzi ${ }^{6}$
}

Islamic Faculty, Nurul Jadid University, Paiton, Probolinggo, Indonesia ${ }^{1}$ Islamic Faculty, Nurul Jadid University, Paiton, Probolinggo, Indonesia ${ }^{2}$ Islamic Faculty, Nurul Jadid University, Paiton, Probolinggo, Indonesia ${ }^{3}$ Islamic Faculty, Nurul Jadid University, Paiton, Probolinggo, Indonesia ${ }^{4}$ Faculty of Health, Nurul Jadid University, Paiton, Probolinggo, Indonesia ${ }^{5}$ Departement of Islamic Education, IAI Zainul Hasan, Probolinggo, Indonesia ${ }^{6}$

\{syaifulislam182@gmail.com ${ }^{1}$, yayahdaddy@gmail.com ${ }^{2}$, alfajri002@gmail.com ${ }^{3}$, suksesniken@gmail.com ${ }^{4}$, handono.hfc@gmail.com ${ }^{5}$, fauzi_nov4@yahoo.co.id $\left.{ }^{6}\right\}$

\begin{abstract}
This research intends to know the effect of OK4R in English reading comprehension. The sample is 32 eleven graders of MA Nurul Jadid Paiton. A pretest-posttest design was used as a research design. The data was analyzed by Paired Sample T-test. The result shows significant differences between means $(.000<.05)$. It means that OK4R distribute the successful of learning reading
\end{abstract}

Keywords: OK4R, Reading Comprehension

\section{Introduction}

Reading is one of the important English skills that have to be mastered by students since it always supports their achievement for present and future [1]. Because of the essence of reading skill for students' life, reading becomes a skill that must be taught at school. Even though students have learned a reading lesson, they are still difficult in reaching the main goal of reading which comprehension is.

According to Patel and Jain, reading is the most beneficial and substantial skill for people [2]. It means that with reading the students can improve their knowledge, and also get available information. Reading is also something significant and indispensable for the student since the success of their study counts on a terrific part of their ability to read. The students' ability related to the teacher ways she/ he explain the material.

Linse and Nunan state that reading comprehension is very complex because it requires a high level of thinking it more than just decode specific word [3]. It can be understood that when someone wants to comprehend a text, he should think aloud because he does not only translate the word that he read on the text, but he should also obtain the meaning that writer tells on the text, and it is not easy.

By reading, students will learn something new. Because reading is an alive process of understanding the printed words, hence, they must know how to learn from reading. Reading is the foundation of all knowledge. Both the textbook and the extracurricular reading materials become a source of vocabularies and phrases to readers, to embellish their spoken language skill and writing ability. 
Good English reading ability is an effective way to gain the latest information as it is needed. For inclusion, our industrial and commercial circles continuously establish the internationalization and globalization. It is a crucial needs of brilliant English person. Strengthening the ability of reading will be essential for us to support individual ability in competing. In teaching reading, teachers should consider many aspects essential in reading comprehension [4]. Teachers are one of the important factors that can determine the success or failure of students in learning [5].

Therefore, the teachers can use the appropriate method of learning for the students in understanding texts that can improve and develop their reading ability, even easy to find information from the text. By OK4R (Overview, Key Ideas, Read, Recall, Reflect, Review) method it can improve the students in learning reading text and easier for the students to work on assignments.

\section{Literature review}

\subsection{Definition of OK4R Method}

In teaching reading, there are many methods that can be applied by the teacher. One of them is "OK4R" method. According to Robinson states that "OK4R" is a method that can assist the student focus on studying and prioritizing the data in a way that discloses directly to how they will be questioned to use that in a test [6]. It means that this method is a method of reading a textbook so that the information they read really do enter their long-term memory.

Also, Peterson (2006) states that "OK4R" method is instead of just starting at the beginning and reading through to the end, you'll do the assignment a lot and remember a lot more if you take the time to follow it [7]. This method asks students to focus on the topic. Then, the students can answer the question of the text given by the teacher. So, this method can assist the student in a learning process with easily.

Furthermore, Agbebire states that "OK4R" method is an effective way to get the best out of any students the acronym means in order to use this method, firstly, you must overview the material in which process evaluate it if it contains the basic ideas and take notes of the key points that will guide you in reading [8]. Next is to read in detail the topic, during which jot down of noticeable points to remember what had been then reflected on the points by connecting them with other ideas or something common that will help its understanding. After the reflect on areas, then go through the material again to get a better understanding of difficult or unclear areas and those of poor understanding. It is most useful in subject areas with more of continuous reading than analysis such as the management sciences, commercial and art subjects.

According to Paul, OK4R is the method of reading with help think about what want to get from a text and remember information well. It allows the students to be easier for reading the text and understand what has been read them[9]. This method is very petrified students in reading. Then, Kesselman and Peterson stated that OK4R is a method for reading material which you are expected to remember or to use in an assignment [10]. It means this method can help the students to develop their reading comprehension. The students read and discuss the text with peers. It makes the students will complete the assignment much faster and remember much more.

Based on some definition above, it can be resumed that, this method can help them to lose their perception that reading is difficult to learn and through the steps in a method, the students will be easier to comprehend about text, and that can help students to understand what they 
read. It is easily used in understanding the text. So, the students will get additional information or ideas after reading.

\subsection{Steps of OK4R Method}

According to Peterson, the procedures of "OK4R" method in the following:

a. Overview. Take about five minutes to read the introductory and summary paragraphs of the assignment. Then, read side heading or topic sentences, if there are not headings, to determine general content and sequence of the topic, locate the main division.

b. Key Items. Distinguish key ideas form secondary ideas and supporting materials. Pick out the key ideas the author is making. Change headings into questions by inserting words like what, how, who, why, when.

c. Read. Read the lines or paragraph consecutively to answer your question and to see how supporting materials clarify or prove key points. Don't try to read too quickly at this stage.

d. Recall. After reading, test your memory and understanding. Try to say or write down the main points. Then, make a summary or go back and underline or highlight.

e. Reflect. When you have finished reading and made your notes, sit back and think about what you have read. Try to relate it to something in your experience. Talk about what you have read.

f. Review. At a later time, go over the text again to review material and refresh your memory. To keep the material fresh in your mind, review it now and then. Reread your notes and try to say or rewrite the main points until they are firmly in your mind [10].

\subsection{Reading Comprehension}

According to Rosenblatt in Moreillon, reading is communication among the reader, the text, and the intention of the author. According to Snow, reading comprehension needs the process of drawing out and building meaning simultaneously through interaction and involvement with written language.

According to Anderson et al. in Graham et al., comprehension is the process of coding meaning by coordinating some complex processes that include word reading, word and world knowledge, and fluency. And according to Willis, reading comprehension covers how the brain takes in new information through a variety of neural networks using patterns, categories, and relational connections, and builds the new data into comprehended knowledge.

Debra et al. said that Reading is the key to open doors to all students and Comprehension refers to how struggling readers make sense of the written page in any content area. Serravallo said Comprehension is the core of what it means to read and Reading is thinking and comprehending and getting at the meaning behind a text (Serravallo, 2010). Duffy said that comprehension is the core of reading because the goal of printed language is the communication of messages (Duffy, 2009). And according to Baker et al., Reading is a complex process involving a network of cognitive actions that work together to construct meaning (Dorn \& Soffos, 2005).

Based on the explanation above, the researcher concludes that reading is the process to get the main idea, information, and message from the author. Comprehension is the key to a missing element in reading instruction, how we can get information and interpret it into a deeper meaning of the text. 
To learn reading, the students should have good comprehension to understand the text. Comprehension cannot be separated from reading because reading aims to comprehend what they have been read. Reading comprehension is the way toward building importance by organizing various complex procedures that include word reading, word and world knowledge, and fluency.

Reading comprehension is not alone as an application of learning theory [11], but it is an outstanding example of the challenges facing teacher and students who need to dedicate time, effort, motivation and growing skills to the development of fluent reading ability. In other words, reading comprehension is a process that can make the readers use some strategies and also combine with their knowledge to comprehend something that they are reading or understanding about what has been read. To develop the students' comprehension, the students have to know which aptitudes and procedures are proper for the sort of content and see how to apply them to achieve the reading purpose.

From the above definitions, it can be concluded that Comprehension is the mind act or the power of understanding. When one reads something, he actively goes along to comprehend what the writers' intended message by predicting, evaluating, selecting, significant details, organizing, etc. Therefore, reading comprehension means understanding what has been read. It is an active process that depends on not only comprehension skill, but also readers' experience and prior knowledge.

\subsection{Components of Reading Comprehension}

According to Brown, there are eight components of reading comprehension features. They are the main idea, expression/idiom/phrase in context, inference, grammatical feature, detail including facts not written, supporting the idea, and vocabulary in context [12]. But in this research, the writer only discusses five components which are appropriate for the senior high school curriculum, as follow:

a. Finding Detail Information. It requires readers to scan specific details. Nunan says that while reading, the readers must be able to recognize the detail information such as a person, places, events, and time. The detail information questions are generally prepared to focus on wh-questions to obtaining information [13].

b. They are identifying the Main Idea. The main idea is what the author wants you to know about the topic. Efficient readers understand not only the ideas but also the relative significances as expressed by the writer. It is selected in the beginning, middle, and at the end of the paragraph. Sometimes, the main idea is not stated clearly [14].

c. You are locating the meaning of vocabulary context. When you encounter an unfamiliar word, a good strategy is to infer (or guess) its meaning from the context. You may not always be able to infer an exact meaning, but you can often get the general meaning enough to continue reading with understanding [15].

d. Identifying references. To avoid repeated words or phrases, the authors use reference words. Nuttal says that recognizing reference words and being able to identify the words or phrase to which they refer will help the reader understand the reading passage. The exercise helps learners to recognize some of the signals that shown a sentence related to something that has been mentioned elsewhere in the text [16].

They are making inference from reading the text. Good readers make inferences as they read. That is, in addition to reading the words, they use their imagination and their knowledge about the world to fill in actualities and thoughts that are not expressed in the content. This is sometimes called "reading between the lines." It is often necessary to read between the lines 
because a writer cannot include all the possible information about a topic or situation. Writers leave out information that they think readers will know already or will be able to guess [17].

\section{Method}

This research applied one group of pretest-posttest design. It was conducted at MA Nurul Jadid Paiton Probolinggo East Java. The sample of this research was eleven grader students of Science Program. It consists of 32 students. Reading comprehension test was used as instrument pretest and posttest. The test items are 45 . The students were asked to answer in 90 minutes. The type of test is multiple-choice. The test used dichotomous scoring where the correct answer will score " 1 " and the wrong answer will score " 0 ".

\section{Result and discussion}

Mean of pretest and posttest consecutively 22.2 and 28.75. The test is normal based on the Q-Q plot. It can be seen in the description below;
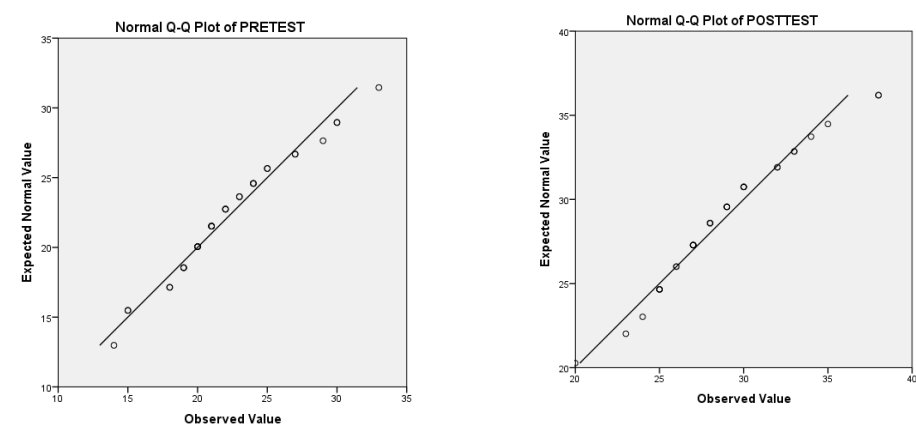

The picture explains that each item of the test is close to the line. It means that the data has normal distribution. Based on computation by SPSS, it was found that the test has homogeneity of variance $(0.680>0.05)$. Then, to know the significant differences between means, it is computed by Paired Sample T-test. And result pre-test and post-test shows significant differences between means $(.000<.05)$. It means that OK4R distribute the successful of learning reading.

$\mathrm{OK} 4 \mathrm{R}$ is a very useful technique to teach reading. It requires students to do step by step to comprehend the text. And also, the students have a chance to comprehend the text by bottomup strategy. Because they construct the meaning from the text.

Applying OK4R in the teaching and learning process will help the teachers to teach easier on reading comprehension. And for the students, they will get more knowledge when reading a text. Or they can apply this technique to read articles outside the classroom.

\section{References}

[1] B. T. Suryanto, "Written Grammar Feedback on Students' Writing with Visual Learning Style,” J. Pedagog., vol. 5, no. 1, pp. 1-18, 2018.

[2] M. F. Patel and P. M. Jain, English language teaching. Banashankari: Sunrise 
Publishers and Distributors, 2008.

[3] C. T. Linse and D. Nunan, Practical English language teaching: Young learners. McGraw-Hill, 2005.

[4] S. Islam and E. Santoso, "The Effectiveness of Using Authentic Texts in The Teaching Reading Comprehension," ETERNAL (English, Teaching, Learn. Res. Journal), vol. 4, no. 2, pp. 166-180, 2018.

[5] M. W. and I. M. Syaiful Islam, Hasan Baharun, Chusnul Muali, Moh. Idil Ghufron, Mushfi el Iq Bali, "To Boost Students' Motivation and Achievement through Blended Learning," J. Phys. Conf. Ser., vol. 1114 01204, pp. 1-11, 2018.

[6] M. Safitri, "The Effectiveness of OK4R Strategy to Teach Reading Comprehension of Recount Text (An Experimental Study in SMP Muhammadiyah Ngemplak in Academic Year 2016/2017)," Universitas PGRI Yogyakarta, 2017.

[7] S. Wulandari and Z. Amri, "Using OK4R in Improving Senior High School Students'reading Comprehension,” J. English Lang. Teach., vol. 1, no. 2, pp. 546-555, 2013.

[8] J. Agbebire, "Strategies for Academic Excellence Part 4." 2012.

[9] P. D. Nolting, Winning at math: Your guide to learning mathematics through successful study skills. Academic Success Press Inc., 2002.

[10] J. Kesselman-Turkel and F. Peterson, Study Smarts: How to Learn More in Less Time. Wisconsin: Univ of Wisconsin Press, 2004.

[11] M. Husni, “Analisis Komparatif dan Sintesa Teori Belajar Konvensional dengan Teori Belajar dalam Islam,” J. Pedagog., vol. 5, no. 1, pp. 124-142, 2018.

[12] B. H. Douglas, "Language Assessment Principle and Classroom Practices," NY Pearson Educ., 2004.

[13] D. Nunan, Language teaching methodology, vol. 192. New York: prentice hall, 1991.

[14] K. T. McWhorter, Study and thinking skills in college. Scott Foresman, 1988.

[15] W. Grabe, Reading in a second language: Moving from theory to practice. Ernst Klett Sprachen, 2009.

[16] C. Nuttall, "Teaching Reading Skills in a Foreign Language. Practical Language Teaching. Eds. Marion Geddes and Gill Sturtridge.” London: Heinemann Educational Books, 1982.

[17] I. S. P. Nation, Teaching ESL/EFL reading and writing. Routledge, 2008. 